\title{
DSG3 Gene
}

National Cancer Institute

\section{Source}

National Cancer Institute. DSG3 Gene. NCI Thesaurus. Code C101148.

This gene plays a role in cell-cell adhesion. 